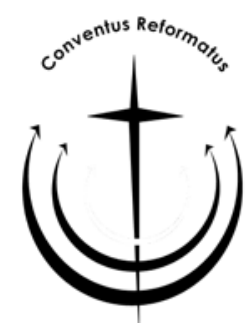

\title{
The influence of Calvin's theology on the Conventus of Reformational Churches in Southern Africa
}

\author{
C.J. Smit \\ School of Ecclesiastical Studies \\ Potchefstroom Campus \\ North-West University \\ POTCHEFSTROOM \\ E-mail: neelssmit@lantic.net
}

\begin{abstract}
The influence of Calvin's theology on the Conventus of Reformational Churches in Southern Africa

The need for an ecumenical body for reformational churches in Southern Africa has been felt since the early 1990s. The key matter explored in this article is the question whether the composition and modus operandi of the Conventus reflect a trend in the ecumenical movement in which Calvin's theological approach to ecumenism is clearly discernible. To answer the question, Calvin's view of church unity and ecumenism is briefly outlined. Secondly, the "Calvinist" way of composition and functioning of the Conventus, because of the nature of this publication which is initiated by the Conventus, are traced and placed on record.
\end{abstract}

Calvin was a fervent champion of church unity. To him ecumenism was a "sine qua non". He was even prepared to overlook serious disagreements in the debate for the sake of unity in the reformational community. Scrutiny of the composition, goals and functioning of the Conventus clearly reveals the impact of Calvinist approach to ecumenism.

\section{Opsomming}

Die invloed van Calvyn se teologie op die Konvent van Reformatoriese Kerke in Suider-Afrika

Die behoefte vir 'n ekumeniese liggaam vir reformatoriese kerke in Suider-Afrika het vroeg in die negentigerjare ontstaan. Die kernvraag wat hier nagegaan word, is of die samestelling en die 
werkswyse van die Konvent 'n ontwikkeling in die ekumeniese beweging is waarin Calvyn se teologiese benadering tot ekumenisiteit ' $n$ beduidende neerslag toon. Om die vraag te beantwoord, word eerstens oorsigtelik ingegaan op Calvyn se beskouing van kerkeenheid en ekumenisiteit. Tweedens word die "Calvinistiese" wyse van die samestelling en die funksionering van die Konvent nagegaan en geboekstaaf, ter wille van die aard van hierdie publikasie wat deur die Konvent geïnisieer is.

Calvyn het hom voluit vir kerkeenheid beywer. Ekumenisiteit was vir hom 'n noodwendigheid. Hy was selfs bereid om ernstige verskilpunte buite diskussie te laat ter wille van eenheid in die geloofsgemeenskap. Uit die samestelling, doelstellings en funksionering van die Konvent blyk dat Calvyn se benadering tot ekumenisiteit daarin 'n neerslag vind.

\section{Introduction}

The ideal of establishing an ecumenical body of reformed churches in Southern Africa first surfaced in various church communities in the early 1990s. The erstwhile Tussenkerklike Kommissie (TKK) of the Reformed Churches in South Africa (RCSA), the Dutch Reformed Church (DRC) and the Nederduitsch Hervormde Kerk van Afrika (NHKA) set up a working commission to formulate this ideal and explore the possibility of a pilot committee drawn from all reformed church communities in Southern Africa (Smit, 2009b:145). The question considered in this article is whether the composition and modus operandi of the Conventus reflect a trend in the ecumenical movement in which Calvin's theological approach to ecumenism is clearly discernible. The answer to the question is important, because it will indicate whether Calvin's approach to ecumenism fundamentally directs the operation of the Conventus. To answer the question we first look cursorily at Calvin's view of church unity and ecumenism, and then turn to the nature of the composition and functioning of the Conventus. For historical purposes the members of everyone of the preparatory meetings for establishing the Conventus are rendered here.

\section{Calvin's view of church unity and ecumenism}

To Calvin church unity was vitally important. This is evident in his exegetical work, especially as systematised in his Institutes (Nijenhuis, 1959:1, 2) and emerges in a large body of his collected letters (Calvin, 1980). To Calvin (1964-1966; Inst. 1. Preface) the church is not primarily a structure or a visible form, but comprises all believers 
who embrace the pure proclamation of God's Word and the proper ministry of the sacraments. Calvin (1964-1966) finds the division of the church into different denominations totally unacceptable (Inst. 4.1.2; 4.1.10; 4.13.14) - in fact, he strongly condemns church fragmentation (Calvin, 1972:21-24).

Calvin's widely quoted (1980:133) comment in his letter to Cranmer, indicating that wherever he is needed to further church unity he would be prepared to cross ten oceans, illustrates his earnest concern about the cause. He even aligned himself in faith with those of the reformation to whose theological ideas and church organisation he had serious objections. In his arguments about certain ecclesiastic issues addressed to the Scandinavian rulers, who were of the Lutheran persuasion, he makes no mention of points on which he disagreed with Lutheranism. Another example is that his grave misgivings about Melanchthon's doctrine of predestination - a key doctrine in his own theology - never affected his religious solidarity and close ties with his fellow reformer. Neither did his differences from the Lutheran conception of the Eucharist detract from his sense of unity with them. Likewise differences about the church's organisational arrangements in disparate historical and cultural circumstances did not deter him from championing scripturally based unity among the dispersed protestants of his day (Nijenhuis, 1959:220).

Calvin was prepared to leave issues that he considered important aside in religious debates in order to pursue a higher goal - the communion and unity of all believers. Apart from the doctrine of predestination, these included liturgical practices and aspects of canon law such as church discipline and the doctrine on the official ministries (Nijenhuis, 1959:90, 91).

Calvin explicitly stated that not every difference of opinion necessarily had to lead to secession. He wrote to André Zébédée, a fanatical Zwinglian, that he must ensure that brotherly ties were maintained "for we should not part without good reason with those whom the Lord has joined to us as partners in his work" (Nijenhuis, 1959:113).

In 1549 the Consensus Tigurinus was established in an attempt to reconcile Lutheranism and Zwinglianism. Calvin contributed significantly. The major controversy was about a crucial issue: the conception of the Eucharist. The big division between Zürich and Wittenberg was the Zwinglians' spiritualised doctrine of the Eucharist and the Lutheran notion of Christ's real presence in the sacrament. With his realistic, yet spiritual view of the sacrament, Calvin was 
midway between the Zwinglian and the Lutheran positions. Despite this he felt that this difference need not threaten the unity of the religious community (Nijenhuis, 1959:221, 222; Dankbaar, 1982:165 ff.).

Notwithstanding his vehement dissension with the papacy Calvin never wanted to break away from the Roman Catholic Church. What he wanted to do was to restore the church from its decay to its original purity and obedience to Christ. Thus he actually acknowledged that there were still vestiges of the true church in the Roman Catholic Church, especially because the sacrament of baptism was still in its keeping. Calvin was unequivocally opposed to secession aimed at establishing a community of perfect Christians. His thinking was catholic, not sectarian. Indeed, he indefatigably strove for and championed a unified, ecumenical church in all countries (Dankbaar, 1982:195). To Calvin church unity was fundamentally grounded in the absolutely essential confession of the Christian faith, which he felt left ample leeway for ecumenism and permitted clear identification of issues on which churches may differ without any threat to their unity (Van 't Spijker, 2001:194).

\section{Composition and functioning of the Conventus}

In the composition and functioning of the Conventus Calvin's approach to ecumenism is evident. On the firm and wide basis of the Scripture a range of Southern African reformed church communities were gathered in this new ecumenical body. Once the erstwhile TKK had recognised the need for an actual ecumenical convention of denominations with a reformed orientation, an initial working commission was constituted as follows (Smit, 2008:iii-vii; 2009a:464466; 2009b:145, 146):

- Prof. P.J. Strauss and Dr. H. Grobler of the DRC

- Proff. H.G. van der Westhuizen and S.J. Botha of the NHKA

- Prof. A. le R. du Plooy and Dr. C.J. Smit (chairman) of the RCSA

On 13 October 1995 the working commission met at Potchefstroom. The ideal of an ecumenical convention of denominations in Southern Africa that based themselves on reformed creedal texts was formulated as follows:

The essence and attributes of the church of Jesus Christ present us as churches confessing the same creed with a calling to attest our faith in the world in harmony with one 
another. A regular assembly of delegates from the Reformed Churches can provide churches of the same reformed confession with a canonical basis and presence in the same society.

After planning and discussions by the working commission with relevant delegates from various denominations it was decided to create a pilot committee.

The pilot committee met on the Vaal Triangle Campus of the erstwhile PU vir CHO on 4 September 1997. It was composed of representatives of church communities that responded to invitations addressed to virtually all reformed church communities in Southern Africa.

- Afrikaanse Protestantse Kerk: Rev. M.C. Adendorff and Dr. C.I. van Heerden

- Christelike Gereformeerde Kerk in Suid-Afrika: Rev. R. Verreynne

- Reformed Churches in South Africa: Prof. A. le R. du Plooy and Dr. C.J. Smit

- Reformed Churches in South Africa (the former Midland synod): Rev. M.A. Modise and Rev. J.A.M. Letsela

- Reformed Churches in South Africa (the former Soutpansberg synod): Rev. T.E. Liphadzi, Rev. M.S. Nefefe and Prof. T.C. Rabali

- Nederduitsch Hervormde Kerk van Afrika: Proff. S.J. Botha and I.W.C. van Wyk

- Nederduitsch Hervormde Kerk in Suidelike-Afrika: Rev. M.J. Manala

- Dutch Reformed Church: Drs. H.S. Grobler and W.J. Bruwer. (Apologies were received from Prof. P.J. Strauss, Rev. Freek Swanepoel and Dr. Willie Botha)

- Dutch Reformed Church in Africa (Phororo): Rev. S.G. Lamprecht

Dr. C.J. Smit was appointed chairman, Rev. M.A. Modise became vice chairman and Dr. H.S. Grobler secretary.

After in-depth talks the pilot committee in its turn appointed a second working committee to do the spadework for establishing a Conven- 
tus. The meaning for the original Latin conventus is an ad hoc gathering, a fellowship of believers who do not gather in the strict sense by means of church representatives in a major assembly, and it is for this reason not a gathering of church government, but rather a gathering of church leaders and spokesmen to determine a direction (Pont, 1981:70; Aalders, 1919:75).

The mentioned working committee defined the nature of a possible Conventus as follows (Smit, 2008:iii-vii):

- Not necessarily within the same denomination, not necessarily any form of structural unity among churches, not necessarily a fraternal relationship;

BUT:

- a channel for common witness to common circumstances, in the same country and society;

- on the basis of the same reformed confession, without compromising individual churches in regard to their character, ethos and history.

In the context of this article on Calvin's approach to ecumenism and the Conventus the point to be noted is that the Conventus was constituted on the basis of the same reformed confession. This meant that collaborating denominations had to subscribe at least to one of the recognised reformed creeds.

After several meetings a basic document was thrashed out, on the strength of which reformational churches met via their delegates on the basis of our common faith, confession and reformed tradition to

- witness prophetically to our community and, if necessary, to society and the authorities;

- provide mutual support and assistance where it is requested; and

- coordinate possible cooperation with regard to common interests and responsibilities in society (Smit, 2008:iii-vii).

In addition they reached the following agreement:

Whereas conventional ecumenical bodies form a structure in which ecumenism is practised as an extension of (even a substitute for) church unity on an ongoing basis across language, cultural and national boundaries, the Conventus seeks to 
provide an ad hoc forum for reformational churches in Southern Africa to witness on common issues and, where applicable, cooperate.

The work of the pilot committee and its working committee culminated in the First Conventus of Reformed Churches in Southern Africa (Smit, 2008:iii-vii). It was inaugurated at the Gereformeerde Kerk Wapadrant in Pretoria on 10 March 1998.

The following delegates of denominations attended the occasion:

- Afrikaanse Protestantse Kerk: Prof. I.A. Brink, Rev. M.C. Adendorff and Rev. M.M. Rautenbach

- Calvyn Protestantse Kerk: Rev. M.F. Abrahamse and Rev. M.P. Cloete

- Christelike Gereformeerde Kerk in Suid-Afrika: Rev. D. Davids, Rev. J.P. Tromp, candidate C. Bodenstein, Rev. I.B. Weber (observer) and Rev. J.S. le Roux (observer)

- Free Church of Scotland in SA: Rev. B. Tahoo

- Reformed Churches in South Africa: Dr. C.J. Smit, Prof. A. le R. du Plooy, Dr. C.F.C. Coetzee, Dr. N.P. Heystek (observer), Dr. J.L. Venter (observer) and Prof. P.J. Coetzee (observer)

- Reformed Churches in South Africa (the former Midlands synod): Rev. M.A. Modise and Ds. J.A.M. Letsela

- Reformed Churches in South Africa (the former Soutpansberg synod): Rev. T.E. Liphadzi and Rev. M.S. Nefefe

- Nederduitsch Hervormde Kerk van Afrika: Prof. S.J. Botha, Prof. I.W.C. van Wyk and Dr. G.M.J. van Wyk (observer)

- Dutch Reformed Church: Dr. M. Smuts, Prof. P.J. Strauss, Prof. P. Coertzen, Prof. P.G.J. Meiring (observer), Dr. W.J. Bruwer (observer)

- Dutch Reformed Church in Africa (Phororo): Rev. S.M. Kuekue and Rev. K.P. Motsweng

- Vrye Gereformeerde Kerke in Suid-Afrika: Rev. J.R. Visser

Apologies were offered by the Church of England in South Africa, the English Reformed Church of Randburg, the Rynse Kerk and the United Congregational Church. 
The chairman of the First Conventus was Dr. C.J. Smit, the vice chairman was Prof. A. le R. du Plooy and the secretary was Dr. C.F.C. Coetzee. The cardinal item on the agenda of the First Conventus was to agree on the Foundation and Functioning (FFC, 1998) of its operations.

On 10 March 1998, for the first time in nearly three and a half centuries, a joint forum was created for the Reformed faith to deliberate and act together.

The Conventus's modus operandi is laid down in the Foundation and Functioning of the Conventus (FFC, 1998:2). Each participant denomination is represented by at most ten delegates. There is no restriction on the number of observers. It is an open meeting. At each annual convention a host church is appointed on a rotating basis. Whereas all denominations represented nominate one member to the Interim Committee, the host church nominates two members to act as chairman and secretary, also at the next convention. The Interim Committee is responsible for all arrangements and the implementation of decisions. A general secretary is appointed to ensure continuity. The agenda of the Conventus is set by the participant denominations and prepared by the Interim Committee.

As for the canonical status of participant denominations, the agreement was as follows (FFC, 1998:1):

The Conventus is an assembly where churches deal with common matters on the basis of their common faith, confession and Reformed tradition, with due regard to the individual nature, ethos and history of each church. The agenda focuses on a Reformed witness in the name of the Conventus. Particular viewpoints of participating churches are not forced upon other participating churches. No church shall dominate another church.

Including denominations that submitted apologies from time to time, the number of participant churches came to at least eleven - out of just over twenty reformed churches in Southern Africa. Currently the following reformed churches are members: The Afrikaanse Protestantse Kerk (observer), the Calvyn Protestantse Kerk, the Christelike Gereformeerde Kerk, the Free Church in South Africa, the Reformed Churches in South Africa, including the erstwhile Midlands Reformed Churches (now part of the RCSA), the Dutch Reformed Church, the Nederduitsch Hervormde Kerk van Afrika, the Presbyterian Church of America, the Reformed Church in Africa, the Rynse Kerk, the Dutch Reformed Church in Africa. 
Over the past eleven years the Conventus has voiced a clear reformed message (cf. Smit, 2008:vi, vii):

- A basis for Days of penitence was established, according to which many more denominations would take part henceforth.

- Testimonies were submitted to government institutions and officials on violence and crime, spending and distribution of funds to combat poverty, the law on abortion, education, work ethics, provision of medical services, churches' relations with government and the like.

- Searching talks were conducted on what being a church entailed proclamation and church building in changing times with due regard to reformed principles. Ministry to members living abroad and the relations of church and state received special attention.

- In collaboration with SEVTO of the University of Pretoria the countrywide Conference on Poverty and Inequality was held in 2001.

- In 2002 the focus was on the church in society and on church and state.

- In 2003 the reformed legacy was the focus and the so-called New Reformation was discussed in depth.

- In 2004 the key theme was whether the church brought hope for Southern Africa. The first issue of the Conventus's internet journal appeared, entitled inter.con. of whom Dr. C.J. Smit was the interim editor until 2006, when Dr. N. Vorster took over. Technical editing is in the hands of Rev. E. Fourie.

- In 2005 a conference was held on crime and violence in Southern Africa.

- In 2006 a reformed perspective on focal issues in education was presented.

- In 2007 a dialogue was conducted on scriptural principles of church unity.

- In 2008 dialogue centred on making church unity visible.

- In 2009 the dialogue on church unity was extended to a delegation from the Lutheran Church in South Africa and Namibia. This is a considerable extention of the original goal, viz. "reformed churches". In fact, with this the Conventus broadened it's 
original basis in 2009 to include the Lutherian tradition in it's concept of "reformational churches".

After 350 years a Conventus of Reformational Churches in Southern Africa was launched, which voices a reformed point of view in society and in relation to government.

\section{Conclusion}

From the composition, objectives and functioning of the Conventus of Reformational Churches in Southern Africa over the past twelve years one concludes that Calvin's theology in regard to church unity and ecumenism is reflected in this ecumenical body:

- The Conventus is composed of churches that subscribe to at least one of the reformed creeds which, in a broad sense, are the outcome of Calvin's theology on principle religious matters.

- The objectives of the Conventus are based on confessions arised from the reformation.

- The functioning of the Conventus, both organisationally and in implementing its agenda, obtains Calvin's approach to ecumenism and it reflects Calvin's legacy of commitment to Scripture.

- Overall the Conventus functions by focusing on major aspects of church unity within the framework of the reformed creeds. Possible differences between denominations on biblical interpretation regarding the application or enactment of doctrinal tenets and possible dissent on liturgical and regulatory aspects are left out of the discussions.

Up to the present the following are participating churches: The Calvin Protestant Church, the Christian Reformed Church, the Reformed Churches in South Africa, the Dutch Reformed Church in Africa, the Dutch Reformed Church, the Netherdutch Reformed Church of Africa, the Reformed Church in Africa, the Rhenish Church, the Free Church in South Africa. The following churches consider themselves being in a observing capacity: the Maranatha Reformed Church of Christ, the Moravian Church in South Africa, the United Congregational Church, the Uniting Presbyterian Church and the Free Reformed Churches in South Africa.

\section{List of references}

AALDERS, W.J. 1919. De kerk. (In Bijbelsch-Kerkelijk Woordenboek. Groningen: Wolters. p. 75.) 
CALVIN, J. 1964-1966 [1559]. Institutes of the Christian religion. 2 vols. Trans. by $\mathrm{H}$. Beveridge. Grand Rapids: Eerdmans.

CALVIN, J. 1972. Uitlegging op den eersten en tweeden zendbrief van Paulus aan de Corinthiërs. DI. 2. Trans. by A.M. Donner. Kampen: De Groot.

CALVIN, J. 1980. Letters of John Calvin - selected from the Bonnet edition. Pennsylvania: Banner of Truth Trust.

CONVENTUS OF REFORMATIONAL CHURCHES IN SOUTHERN AFRICA. 1998. Foundation and functioning of the Conventus of Reformational Churches in Southern Africa. (Unpublished.)

DANKBAAR, W.F. 1982. Calvijn - zijn weg en werk. 2nd ed. Nijkerk: Callenbach.

FFC

see CONVENTUS OF REFORMATIONAL CHURCHES IN SOUTHERN AFRICA

NIJENHUIS, W. 1959. Calvinus oecumenicus - Calvijn en de eenheid der kerk in het licht van zijn briefwisseling. 's Gravenhage: Nijhoff.

PONT, A.D. 1981. Die historiese agtergronde van ons kerklike reg. Pretoria: HAUM.

SMIT, C.J. 2008. Posisionering van die Konvent na tien jaar. Conventus Reformatus: Dokumentebundel saamgestel by geleentheid van die Konvent se tiende bestaansjaarviering. p. iii-vii. (Unpublished.)

SMIT, C.J. 2009a. Kan die GKSA na 150 jaar beskou word as 'n stagnante kerkgemeenskap? Ekumenies beoordeel. In die Skriflig, 43(3):447-471.

SMIT, C.J. 2009b. Die GKSA en ekumenisiteit - kerkeenheid oor die wêreld heen. (In Vorster, K., red. Uit dankbaarheid: 1959-2009. Pretoria: Gereformeerde Kerke in Suid-Afrika. p. 139-147.)

VAN 'T SPIJKER, W. 2001. Die Kirche in ihrer Geschichte. Göttingen: V\&R.

\section{Key concepts:}

church

church communities

church unity

ecumenism

Kernbegrippe:

ekumenisiteit

kerk

kerkeenheid

kerkgemeenskappe 
